\title{
Studi Peristiwa Penetapan COVID-19 Sebagai Pandemi Oleh World Health Organization Terhadap Saham Sektor Healthcare Di Bursa Efek Indonesia
}

\author{
Mega Zahira Virtyani ${ }^{1}$; Sri Muljaningsih" ${ }^{2}$;iky Asmara ${ }^{3}$ \\ ${ }^{1}$ Mahasiswa Universitas Pembangunan Nasional Veteran Jawa Timur; ${ }^{2-3}$ Dosen Universitas \\ Pembangunan Nasional Veteran Jawa Timur, \\ email : 17011010029@student.upnjatim.ac.id; muljaningsihsri@gmail.com; \\ kikyasmara25@gmail.com
}

\section{ARTICLES INFORMATION}

ABSTRACT

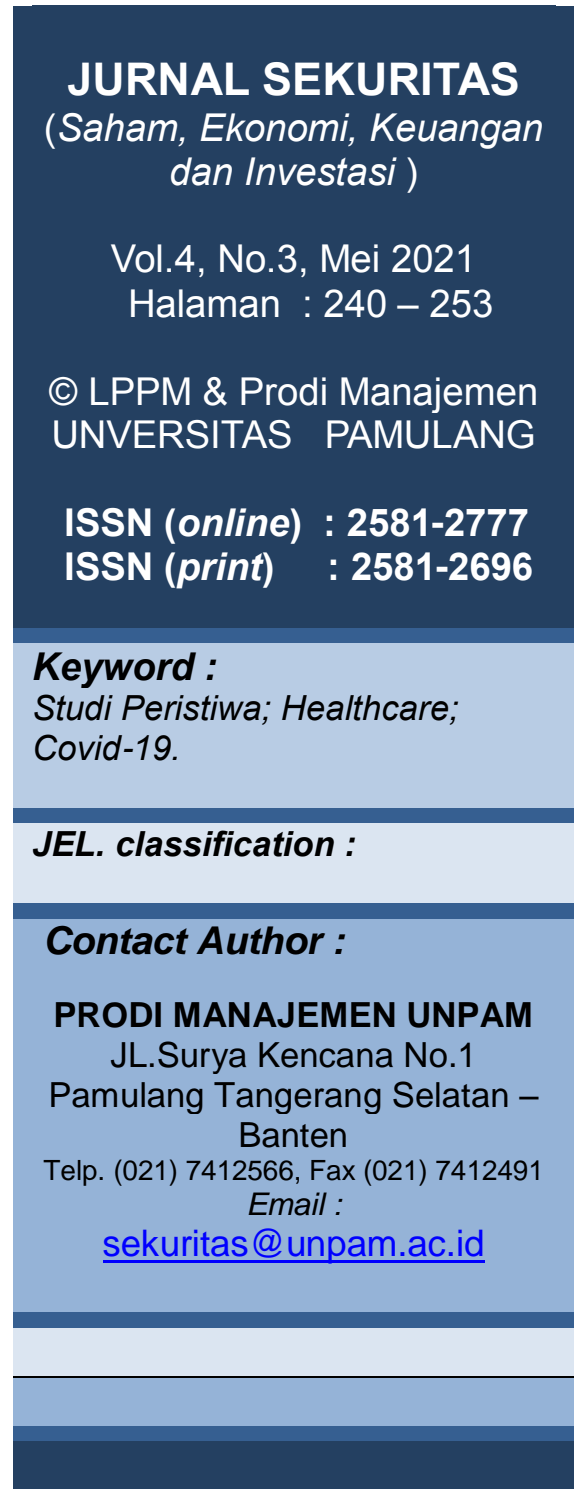

Studi peristiwa merupakan analisis reaksi pasar pada suatu peristiwa. Penelitian ini akan menggunakan studi peristiwa Covid-19 sebagai pandemi oleh WHO terhadap reaksi pasar modal Indonesia khususnya sektor healthcare. Tujuan penelitian ini adalah menganalisis perbedaan reaksi pasar sektor healthcare pada periode sebelum dan periode sesudah peristiwa serta mengetahui kandungan informasi di sekitar peristiwa yang mencerminkan tindakan investor. Populasi penelitian ini yaitu saham sektor healthcare, dari 18 perusahaan sektor healthcare yang dijadikan populasi hanya 14 perusahaan sektor healthcare yang memenuhi kriteria sampel. Metode analisis penelitian ini yaitu paired sample test dan uji t-hitung dengan memakai data harian saham sektor healthcare selama 81 hari untuk periode pengamatan dimana terdiri atas 40 hari untuk periode estimasi dan 41 hari untuk periode jendela. Kesimpulan yang ditemukan pada penelitian ini yaitu tidak adanya perbedaan antara periode sebelum dan periode sesudah peristiwa namun secara matematis perbedaan tersebut menunjukkan sinyal baik. Kandungan informasi yang dicerminkan oleh tindakan investor menunjukkan sinyal baik juga namun terdapat abnormal return yang terjadi berkepanjangan, hal ini mengindikasikan kandungan informasi yang tersedia dari peristiwa dicerminkan secara lambat oleh investor.

Event study is an analysis of market reactions to an event. This research will use event study of Covid-19 as a pandemic by WHO on the reaction of the Indonesian Capital Market, especially the healthcare sector. The purpose of this research are to analyze of market reactions in the healthcare sector between before and after the event and to find out the information content around the event that reflects the actions of investors. The population in this study is stocks of the healthcare sector, there are 18 companies that included on the population and only 14 companies that included of sample criteria. The analysis method used in this research are paired sample $t$ and t-test using daily data on the healthcare sector stocks for 81 days of observation period and 41 days of window period. The results of this research show that there was not difference between before and after the event but mathematically the difference give an indicate good signal. The information content reflected by the actions of investors also show a good signal because there a lot positive abnormal return but there is a lag of abnormal return, this indicates that available information content from the event can reflect slowly by investors. 


\section{A. PENDAHULUAN}

Perkembangan global dewasa ini khususnya pada kuartal I tahun 2020 terjadi fenomena yang mengejutkan, dunia tertekan dengan munculnya pandemi global, yaitu pandemi Covid-19. Tepatnya pada Bulan Maret Tanggal 11 Tahun 2020, organisasi internasional World Health Organization (WHO) menyampaikan bahwa Covid-19 yang sedang merebak di berbagai dunia ditetapkan sebagai pandemi (WHO, 2020). Pengertian dari pandemi Covid-19 yaitu virus dari penyakit Covid-19 telah menyebar dan menular secara luas di dunia. Dimana selama dua minggu terakhir sebelum pengumuman Covid-19 ditetapkan sebagai pandemi, penularan Covid-19 di berbagai negara mengalami peningkatan. Negara-negara harus meningkatkan upaya dalam mendeteksi, menguji, merawat, dan memobilisasi rakyat dengan baik agar masyarakat tidak merasa panik dan cemas atas apa yang terjadi dari peristiwa pandemi Covid-19.

Peristiwa Pandemi Covid-19 mengakibatkan berbagai dampak terhadap keberlangsungan sektor-sektor. Dikarenakan banyak negara melakukan tindakan pencegahan penyebaran Covid-19, dengan mengatur jarak bertrmunya antar orang satu dengan orang lainnya tidak boleh berdekatan (social distancing) hingga kebijakan dilarang untuk pergi dari tempat tinggal (lockdown) (Muliati, 2020). Kebijakan social distancing hingga lockdown diberlakukan di berbagai negara untuk mengupayakan dalam meminimalisir penyebaran virus corona (Covid-19). Sektor yang terdampak juga oleh peristiwa tersebut yaitu sektor ekonomi. Perekonomian global menjadi lesu, hamper seluruh negara mengalami kemrosotan

ekonomi.

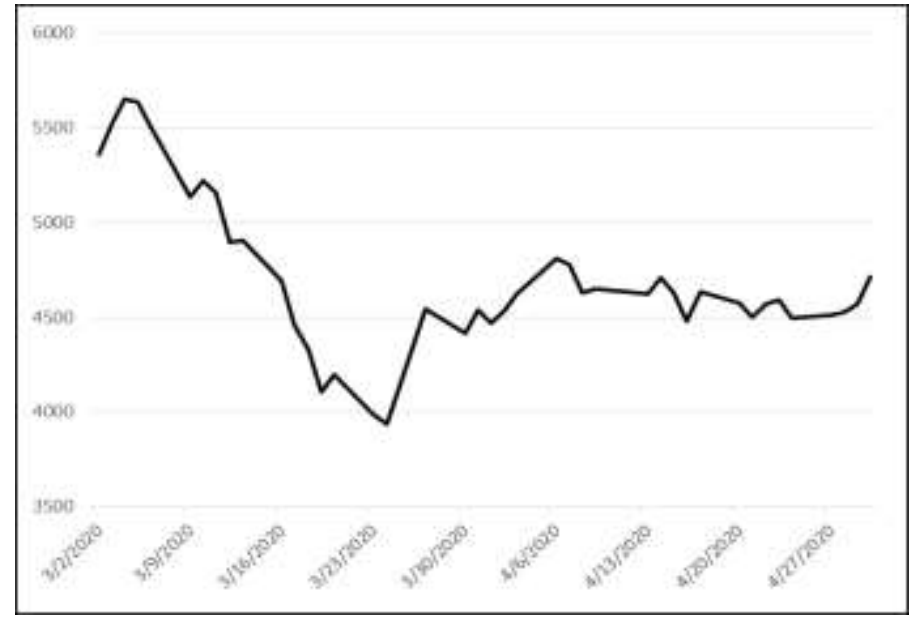

Sumber: data diolah. (2021)

Gambar 1. Pergerakan Indeks Harga Saham Gabungan Bulan Maret - Bulan April 2020

Salah satu bagian dari dampak lesunya ekonomi Indonesia yaitu membuat pasar modal Indonesia menjadi tertekan. Hal tersebut ditunjukkan oleh pergerakan Jakarta Composite Index (IHSG) yang membuktikan terjadinya kemerosotan pada Bulan Maret 2020. Tercatat di Tanggal 02 Maret 2020 penutupan IHSG sebesar 5361 dan pada akhir bulan tanggal 31 Maret 2020 penutupan IHSG sebesar 4538. Bahkan pada tangal 24 Maret 2020 ditutup sebesar 3937, angka tersebut merupakan penutupan IHSG terendah dalam pergerakan IHSG dari awal tahun 2020. Selanjutnya pada Bulan April tahun 2020 pergerakan IHSG mengalami fluktuatif, dapat dikatakan salah satu penyebab IHSG mengalami fluktuatif yaitu akibat dari panic attack para investor dari peristiwa pandemi Covid-19. Berita seputar peristiwa Covid-19 membuat investor resah, sehingga investor ramai-ramlai menjual saham dan berdampak terhadap pergerakan IHSG yang mengalami 
kontraksi. Seluruh investor pasar modal pasti memperhitungkan efeknya sehingga mempengaruhiharga saham-saham yang memberikan reaksi dalam menyesuaikan terhadap peristiwa yang terjadi.

Saham sektor kesehatan, dapat dilihat pada gambar 1.2, sejak awal maret 2020 ratarata harga saham-saham sektor kesehatan (healthcare) mulai mengalami kontraksi pula, hal tersebut dapat terjadi karena rasa cemas dan khawatir para investor sehingga pergerakan rata-rata harga saham sektor kesehatan mengalami kontraksi. Namun, setelah melalui tanggal 24 Maret 2020 pergerakan tersebut menunjukkan laju peningkatan (uptrend). Hal ini berbeda dengan laju pergerakan IHSG. Dengan demikian, merebaknya Covid-19 dapat memberi dampak pada lingkungan ekonomi yang akan mempengaruhi sentimen investor, selanjutnya menyebabkan perubahan harga saham.

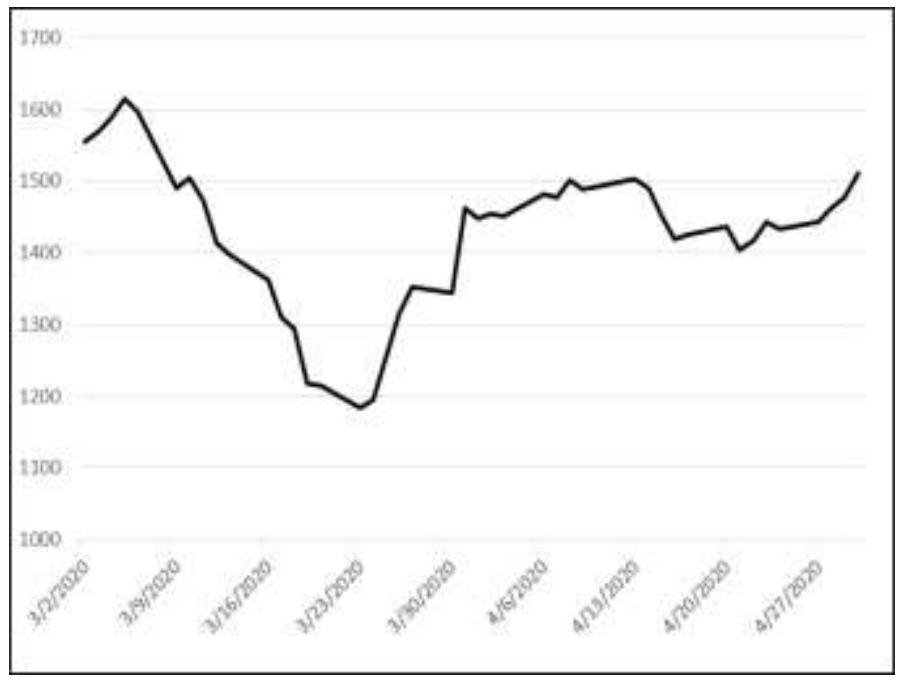

Sumber : data diolah. (2021)

\section{Gambar 2. Pergerakan Rata-Rata Harga Saham Sektor Healthcare \\ Di Bursa Efek Indonesia Pada Bulan Maret - Bulan April 2020}

Saat ini masih belum banyak pengobatan yang pasti untuk mengobati penyakit Covid19. Industri sektor kesehatan membantu pemerintah untuk mengatasi kebutuhan Covid-19, mulai dari tindakan penelitian dan pengembangan vaksin hingga menyeimbangkan rantai pasokan obat-obatan. Seluruh masyarakat mengantisipasi secara individu dalam mengurangi terjangkitnya penularan Covid-19 dengan mematuhi protokol kesehatan, meningkatkan imunitas tubuh, dan makan makanan yang sehat. Hal tersebut dapat meningkatkan daya beli masyarakat khususnya sektor kesehatan dimana dapat meningkatkan kinerja perusahaan dari segi penjualan dan laba. Dalam pasar modal, hal yang sangat diprioritaskan yaitu imbal hasil atau return. Apabila kinerja perusahaan meningkat, maka imbal hasil atau return yang dihasilkan semakin tinggi.

Penelitian sebelumnya (Hindayani, 2020) menggunakan metode studi peristiwa, dimana tujuan dari penelitiannya yaitu menganalisis bagaimana pengaruh dari peristiwa pengumuman terkonfirmasi positif Covid-19 kali pertama di Indonesia terhadap return saham. Periode jendela dalam penelitian tersebut yaitu terdiri atas 10 hari pada periode sebelum peristiwa, 10 hari pada periode setelah peristiwa, dan 1 hari pada tanggal peristiwa. Tanggal terjadinya peristiwa yaitu 2 Maret 2020 pada saat diumumkan kali pertama pasien terkonfirmasi positif Covid-19 oleh Presiden. Berdasarkan penelitian tersebut, simpulannya yaitu tidak ada perbedaan cumulative abnormal return subsektor farmasi, subsektor telekomunikasi, dan subsektor makanan minuman pada periode sebelum dan pada periode sesudah peristiwa pengumuman terkonfirmasi positif Covid-19 pertama kali di Indonesia. Subsektor tersebut, cenderung naik karena banyak dibutuhkan untuk meningkatkan 
kesehatan masyarakat dalam rangka pencegahan Covid-19 serta untuk subsektor telekomunikasi masyarakat membutuhkan internet sebagai alat telekomunikasi di masa pandemi karena mengingat semua kegiatan baik sekolah dan bekerja dilakukan dirumah.

Suatu informasi dapat menimbulkan reaksi pasar jika informasi tersebut mempunyai kandungan nilai ekonomi. Jika ingin membuktikan peristiwa tersebut memberikan dampak positif atau negatif terhadap saham sektor healthcare di Indonesia Stock Exchange (Bursa Efek Indonesia), maka dapat dilakukan pemeriksaan terhadap kandungan informasi pada peristiwa pengumuman terkonfirmasi positif Covid-19 pertama kali di Indonesia sebagai studi peristiwa. Pengujian kandungan informasi dari peristiwa memiliki tujuan untuk mengetahui reaksi atas peristiwa tersebut. Reaksi pasar digambarkan dengan terjadinya perubahan harga dari saham perusahaan. Untuk mengukur reaksi tersebut digunakan perhitungan return atas perubahan harga atau menggunakan perhitungan abnormal return (Jogiyanto, 2017 : 644). Suatu peristiwa yang terkandung informasi terkait dengan peristiwa dapat menghasilkan abnormal return dan sebaliknya peristiwa yang tidak terkandung informasi terkait dengan peristiwa tidak dapat menghasilkan abnormal return terhadap pasar. Abnormal return ialah nilai beda antara realized return dan expected return. Nilai beda dari kedua return dapat berupa nilai beda yang negatif dan nilai beda yang positif. Tanda negatif atau positif dari abnormal return menunjukkan arah bagaiman pasar bereaksi karena peristiwa apakah mengandung kabar baik atau kabar buruk. Jika abnormal return menghasilkan nilai nol, maka menggambarkan bahwa pasar tidak memberi reaksi atas peristiwa yang tejadi.

Berdasarkan uraian yang telah dijelaskan, hal tersebut mendorong peneliti untuk menguji dampak dari penetapan Covid-19 sebagai pandemi oleh WHO terhadap reaksi harga saham-saham sektor kesehatan (healthcare) di Bursa Efek Indonesia. Penelitian ini ditujukan untuk mengetahui reaksi dan kandungan informasi saham sektor healthcare di Bursa Efek Indonesia.

\section{Rumusan Masalah :}

1. Apakah terdapat perbedaan abnormal return saham sektor healthcare di BEI antara periode sebelum dan periode sesudah pengumuman penetapan pandemi Covid-19 sebagai pandemi oleh WHO?

2. Apakah terdapat abnormal return saham sektor healthcare di BEI yang signifikan pada periode sekitar pengumuman penetapan pandemi Covid-19 sebagai pandemi oleh WHO?

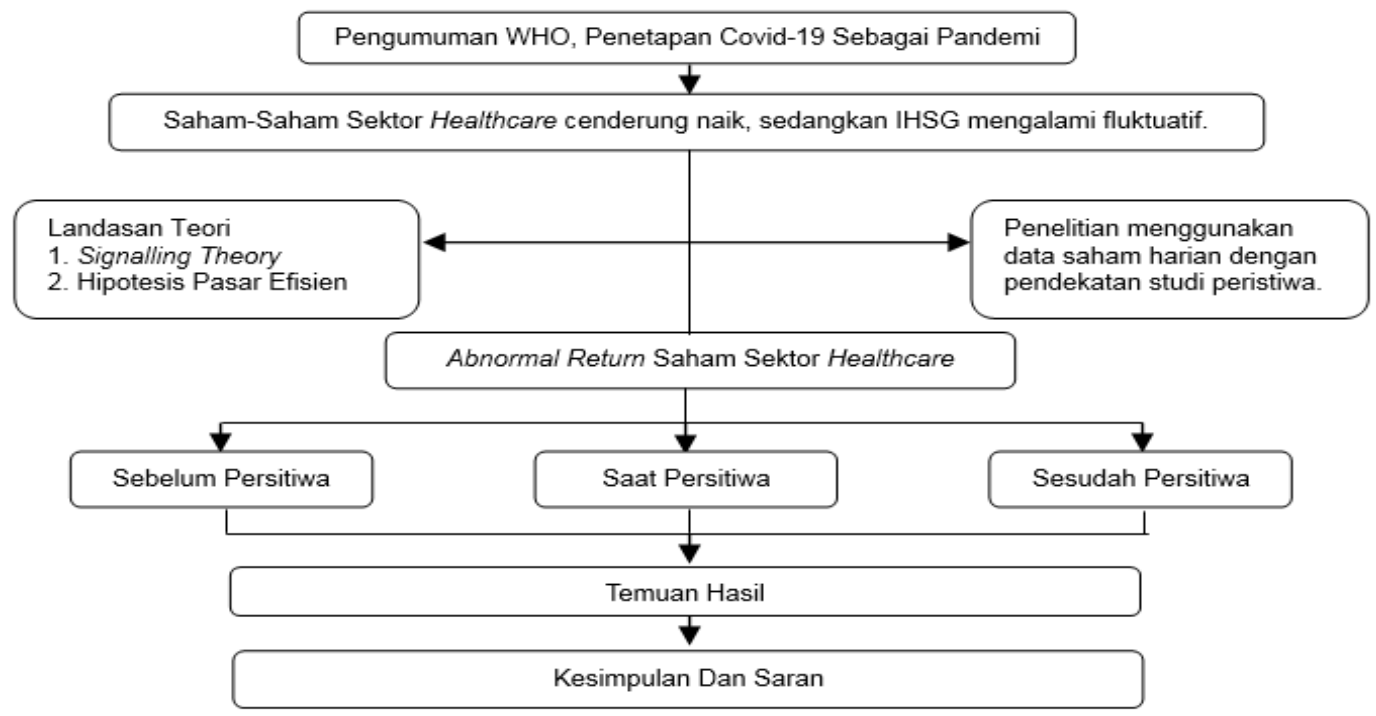

Sumber : Data diolah, (2021).

Gambar 3. Kerangka Berpikir Penelitian

Jurnal SEKURITAS (Saham, Ekonomi, Keuangan dan Investasi ), Vol.4, No.3, Mei 2021.......243 


\section{Hipotesis Penelitian :}

1. Terdapat adanya perbedaan signifikan abnormal return saham sektor healthcare di BEI antara periode sebelum dan periode sesudah pengumuman penetapan penetapan pandemi Covid-19 sebagai pandemi oleh WHO

2. Terdapat abnormal return saham sektor healthcare di BEI yang signifikan di sekitar pengumuman penetapan pandemi Covid-19 sebagai pandemi oleh WHO.

\section{B. KAJIAN LITERATUR}

\section{Signalling theory}

Signalling theory adalah teori yang disampaikan dengan tujuan mengetahui tindakan pihak manajemen yang menyampaikan informasi kepada investor, hal tersebut akan mempengaruhi keputusan investor dalam melihat kondisi perusahaan (Suganda, 2018). Bermacam-macam informasi yang terkandung pada peristiwa kemudian direspon pasar modal dengan dampak perubahan pada pergerakan harga saham. Berita yang baik akan memberi sinyal yang positif pada perdagangan sedangkan berita yang buruk akan memberi sinyal negatif pada perdagangan.

\section{Hipotesis Pasar Efisien}

Konsep hipotesis pasar efisien menjelaskan informasi-informasi yang masuk akan direspon oleh pasar, dan selanjutnya proses bagaimana informasi tersebut dapat memberi pengaruh perubahan atau pergerakan dari harga saham menuju harga keseimbangan yang baru (Tandelilin, 2001). Pasar modal menjadi efisien jika pasar memberikan reaksi yang akurat dan cepat dalam mencapai harga keseimbangan baru dimana dapat dicerminkan sesuai dengan adanya informasi-informasi yang ada. Berdasarkan bentuknya, pasar efisien ditinjau dari ketersediaanya informasi dan respon pelaku pasar dalam mengambil keputusan berdasarkan analisis informasi yang ada.

\section{Event Study}

Studi peristiwa (event study) ialah pengujian reaksi pasar. Studi peristiwa telah banyak dilakukan dalam mengukur pengaruh suatu peristiwa terhadap harga sekuritas perusahaan pada saat terjadinya peristiwa (Jogiyanto, 2018). Pasar bereaksi akibat dari suatu peristiwa karena peristiwa tersebut memiliki kandungan nilai ekonomis dimana bisa mempengaruhi nilai perusahaan. Jika terjadinya suatu peristiwa, maka akan muncul suatu informasi baru terkait dengan nilai perusahaan yang kedapatan oleh publik, sehingga harga saham pada periode sebelumnya akan dikoreksi dari informasi baru tersebut.

\section{Return Saham}

Sebagai investor saham tujuan yang dilakukan yaitu mendapat imbal hasil (returm saham). Definisi dari return saham ialah imbal hasil yang didapatkan dari investasi. Return dibagi menjadi tiga macam yang terdiri dari return sesungguhnya (realized return), return normal (expected return), dan return taknormal (abnormal return).

\section{Return sesungguhnya (realized return)}

Return sesungguhnya (realized return) adalah return yang didapatkan pada waktu ke-t dimana merupakan nilai beda dari harga sekarang relative atas harga sebelumnya, dapat ditulis dengan perhitungan berikut ini:

Realized Return $=\frac{P_{t}-P_{t-1}}{P_{t-1}}$

Jika harga sekuritas sekarang $(\mathrm{Pt})$ lebih tinggi dari harga sekuritas periode lalu $(\mathrm{Pt}-1)$ ini maka mendapatkan keuntungan, sebaliknya jika harga sekuritas sekarang (Pt) lebih rendah dari harga sekuritas periode lalu (Pt-1) ini maka mendapatkan kerugian. 


\section{Return normal (expected return)}

Expected return yaitu return ekpektasian atau return yang menjadi harapan para investor. Besarnya return normal merupakan return yang harusnya didapatkan jika tidak kejadian suatu peristiwa. Jika ternyata terjadi suatu peristiwa, maka return yang didapatkan bukan merupakan expected return lagi, namun adalah realized return. Karena expected return tidak terjadi, maka expected return ini perlu dilakukan estimasi (ekspektasi). Expected return dihitung dengan menggunakan asumsi sumpama jika peristiwa tidak terjadi.

Logikanya, model yang dasarnya menggunakan penyesuaian risiko seharusnya dapat menghasilkan model yang lebih baik, karena berdasarkan ekonomi risiko berperan untuk menentukan return. Model-model sesuaian resiko (risk-adjusted model) mempertimbangkan risiko dalam mengestimasi return normal. Salah satunya yaitu model pasar.

Menghitung expected return menggunakan market model atau model pasar dilakukan melalui langkah-langkah berikut ini:

a. Membentuk model expected dengan mengestimasi data realized selama periode estimasi, b. Menggunakan model expected tersebut untuk mengestimasi expected return pada periode jendela.

c. Model expected (market model) dengan menghitung data realized selama periode estimasi memiliki persamaan seperti dibawah ini :

Keterangan :

$$
R_{i, t}=\alpha_{i}+\beta_{i} \cdot R_{m, t}+\varepsilon_{i, t}
$$

$R_{i, t}=$ realized return sekuritas ke-i di periode estimasi ke-t

$\alpha_{i}=$ intersep untuk sekuritas ke-i

$\beta_{i}=$ koefisien slop yang merupakan beta dari sekuritas ke-i

$R_{m, t}=$ market index return pada periode etimasi ke-t yang dapat dihitung menggunakan rumus $R_{m, t}=\left(\mathrm{IHSG}_{\mathrm{t}}-\mathrm{IHSG}_{\mathrm{t}-1}\right) / \mathrm{IHSG}_{\mathrm{t}-1}$

$\varepsilon_{i, t}=$ kesalahan residu sekuritas ke-i pada periode estimasi ke-t

Untuk menghitung nilai expected return periode ke-t, maka dapat diperoleh model estimasian berikut :

$$
E\left(R_{i, t)}=\alpha_{i}+\beta_{i} \cdot E\left(R_{m, t}\right)\right.
$$

Dalam model expected ini, nilai $E\left(R_{m, t}\right)$ yang digunakan adalah nilai $R_{m, t}$. Setelah model expected telah diperoleh, kemudian tahap selanjutnya yaitu tahap kedua : menghitung expected return untuk hari-hari pada periode jendela menggunakan model estimasi tersebut.

\section{Return taknormal (abnormal return)}

Return taknormal (abnormal return) ialah hasil dari nilai beda yang diperoleh antara realized return yang terjadi dengan expected return yang dapat dihitung seperti dibawah ini :

$\mathrm{RTN}_{\mathrm{i}, \mathrm{t}}=R_{i, t}-E\left(R_{i, t}\right)$

Keterangan :

$\mathrm{RTN}_{\mathrm{i}, \mathrm{t}}=$ return taknormal sekuritas ke-i pada periode peristiwa ke-t.

$R_{i, t} \quad=$ realized return sekuritas ke-i pada periode estimasi ke-t.

$E\left(R_{i, t}\right)=$ expected return sekuritas ke-i pada periode estimasi ke-t.

Dalam mendeteksi abnormal return umumnya tidak dilkaukan pada tiap sekuritas, namun perhitunganya dilakukan secara menyeluruh dengan menguji rerata abnormal return dari seluruh sekuritas pada tiap-tiap hari diperiode peristiwa. Rata-rata abnormal return untuk hari ke-t dapat dihitung berdasarkan rata-rata aritmatika sebagai beriku t: 
$\operatorname{RRTN}_{\mathrm{t}}=\frac{\sum_{i=1}^{N} R T N_{i, t}}{N}$

Keterangan :

$\mathrm{RRTN}_{\mathrm{t}}=$ rerata abnormal return pada hari ke-t.

$\mathrm{RTN}_{\mathrm{i}, \mathrm{t}}=$ abnormal return untuk sekuritas ke-i pada hari ke-t.

$\mathrm{N} \quad=\quad$ jumlah sekuritas yang terpengaruh oleh pengumuman peristiwa.

\section{METODOLOGI PENELITIAN}

Penilitian ini termasuk dalam penelitian kuantitatif. Penelitian kuantitatif merupakan strategi yang digunakan untuk menjawab masalah penelitian dimana datanya berupa angka (Wahidmurni, 2017). Penelitian ini menggunakan studi peristiwa (event study), studi peristiwa adalah studi yang mempelajari reaksi pasar terhadap suatu peristiwa dimana digunakan dalam menguji informasi dari suatu peristiwa.

Periode pengamatan yang digunakan yaitu perdagangan harian saham pada tanggal 12 Desember 2019 hingga 09 April 2020. Dengan even date pada Tanggal 11 Maret 2020, hari penetapan Covid-19 sebagai pandemi oleh WHO. Periode pengamatan dalam penelitian ini memiliki rentang waktu selama 81 hari perdagangan saham. Yang terdiri dari periode estimasi selama 40 hari dan periode jendela selama 41 hari yaitu 20 hari sebelum tanggal pengumuman $(\mathrm{H}-20), 1$ hari saat pengumuman (even date, $\mathrm{H}=0$ ) dan 20 hari sesudah tanggal pengumuman $(\mathrm{H}+20)$.

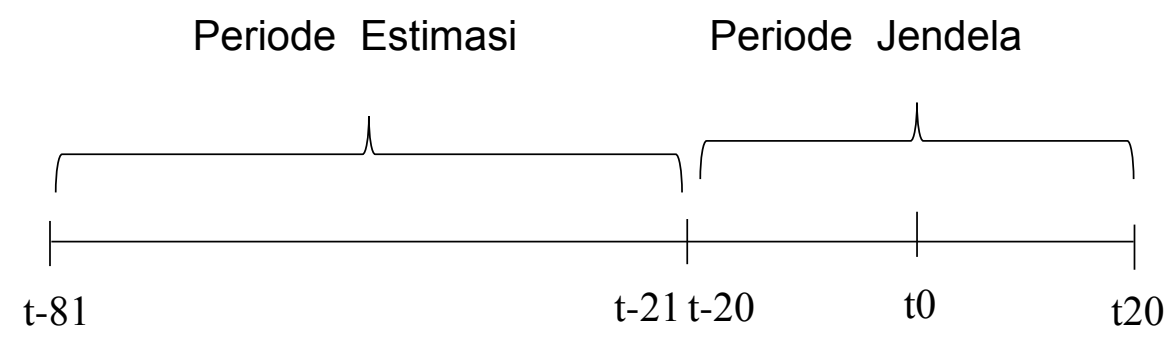

\section{Gambar 4. Periode Pengamatan Penelitian}

Variabel penelitian yang digunakan yaitu abnormal return. Untuk menghindari perbedaan penafsiran dalam pengukuran variabel, berikut pengukuran abnormal return yang digunakan dalam penelitian:

1. Realized Return

2. Return Pasar

3. Expected Return

4. Abnormal Return

\section{Average Abnormal Return}

$$
\begin{array}{ll}
= & R_{i, t}=\frac{P_{t}-P_{t-1}}{P_{t-1}} \\
= & R_{m, t}=\frac{I H S G_{t}-I H S G_{t-1}}{I H S G_{t-1}} \\
= & E\left(R_{i, t)}=\alpha_{i}+\beta_{i} \cdot E\left(R_{m, t}\right)\right. \\
= & \operatorname{RTN}_{\mathrm{i}, \mathrm{t}}=R_{i, t}-E\left(R_{i, t}\right) \\
= & \operatorname{RRTN}_{\mathrm{t}}=\frac{\sum_{i=1}^{N} R T N_{i, t}}{N}
\end{array}
$$

Populasi yang digunakan yaitu perusahaan sektor kesehatan (healthcare) yang teraftar hingga Bulan April Tahun 2020 dalam perdagangan saham di BEI. Sedangkan, metode dalam menentukan sampel menggunakan purposive sampling. Purposive sampling adalah teknik pengambilan atau pemilihan sampel dengan pertimbangan-pertimbangan 
dan kriteria tertentu. Kriteria sampel yang digunakan dalam penelitian ini adalah sebagai berikut :

1. Perusahaan sektor kesehatan yang memiliki data historical price lengkap selama waktu pengamatan yang ditentukan penelitian ini.

2. Perusahaan sektor kesehatan yang memiliki return saham pada periode pengamatan.

3. Perusahaan sektor kesehatan yang terbebas dari peristiwa penggangu (cofounding effect) dari aksi korporasi perusahaan seperti dividen, stock split, right issue, merger, akuisisi dan buy back saham.

Berdasarkan pada kriteria sampel tersebut, terdapat 14 perusahaan sektor kesehatan di Bursa Efek Indonesia yang dapat dijadikan sampel dalam penelitian.

Metode analisis data bertujuan untuk mendeskripsikan uji hipotesis yang akan digunakan sebagai analisis data penelitian. Berikut langkah-langkah dalam menguji hipotesis:

1. Pengujian Normalitas

Untuk menguji normalitas penelitian ini menggunakan uji normalitas kolmogorov smirnov. Uji normalitas kolmogorov smirnov memiliki tujuan untuk mengetahui distribusi data, apakah terdistribusi normal atau tidak (Priyastama, $2020: 119$ ).

2. Pengujian Hipotesis

a. Hipotesis Kesatu

Menguji ada tidaknya abnormal return bukan dilakukan pada tiap sekuritas, namun dilakukan secara menyeluruh dengan menguji rata-rata abnormal return dari seluruh sekuritas untuk tiap-tiap hari pada periode peristiwa (Jogiyanto, 2017: 680). Dalam pengujian hipotesis kesatu untuk mengetahui ada atau tidaknya perbedaan pada abnormal return antara periode sebelum dan periode sesudah peristiwa, maka dilakukan dengan metode komporatif. Jiika hasil uji normalitas ber-distribusi normal maka akan menggunakan uji paired samples test. Uji paired samples $t$ memiliki tujuan untuk menguji data sampel yang saling berpasangan, melihat apakah secara nyata keduanya memiliki ratarata yang berbeda atau tidak. Dua sampel berpasangan bermakna sampel dengan subyek yang sama tapi mengalami perlakuan yang berbeda (Priyastama, 2020 : 88). Dalam pengujian hipotesis ini akan menggunakan program statistik SPSS 13.0 for windows. b. Hipotesis Kedua ( $\mathrm{H} 2)$

Pengujian stastistik pada abnormal return memiliki tujuan untuk mengetahui signifikansi abnormal return yang mungkin terjadi pada periode peristiwa. Maksud dari signifikansi yaitu nilai abnormal return berdasarkan statistik bersignifikansi tidak sama dengan nol (jika bernilai positif untuk kabar baik dan jika bernilai negatif untuk kabar buruk). Pengujian t-test digunakan untuk maksud ini (Jogiyanto, 2017). Uji t-hitung dilakukan menggunakan bantuan aplikasi Microsoft Excel 2013 dalam membantu peneliti menghitung nilai standarisasi abnormal return.

Pengujian-t diestimasi dengan langkah awal standarisasi nilai abnormal return, cara yang diakukan dalam melakukan standarisasi adalah membagi nilai abnormal return dengan nilai kesalahan standar estimasinya. Kesalahan standar estimasi (KSE) yaitu kesalahan standar pada waktu mengestimasi nilai abnormal return. Setelah itu akan dihitung nilai t-hitung seluruh sekurtias pada hari ke-t. Pengujian-t umumnya dilakukan untuk return portofolio atau rata-rata return seluruh k-sekuritas pada hari ke-t di periode peristiwa (Jogiyanto, 2017 : 691). Dengan demikian, untuk menguji hipotesis kedua melalui langkah-langkah sebagai beikut :

1). Menghitung nilai kesalahan standar estimasi (Jogiyanto, $2017: 694)$.

$\mathrm{KSE}_{\mathrm{i}} \quad=\sqrt{\frac{\sum_{j=t 1}^{t 2}(R i j-E(R i j))^{2}}{T 1-2}}$ 
Keterangan :

$\mathrm{KSEi} \quad=$ kesalahan standar estimasi untuk sekuritas ke-i

$\mathrm{Ri}, \mathrm{j} \quad=$ return sekuritas ke-i untuk hari ke-j selama periode estimasi

$\mathrm{E}(\mathrm{Ri}, \mathrm{j}) \quad=$ estimasi return sekuritas ke-i untuk hari ke-j selama periode estimasi

$\mathrm{T} 1=$ jumlah hari di periode estimasi

2). Menghitung standarisasi abnormal return untuk masing-masing sekuritas (Jogiyanto, $2017: 687)$.

$\mathrm{RTNS}_{\mathrm{i}, \mathrm{t}}=\frac{R T N_{i t}}{K S E_{i}}$

Keterangan :

$\mathrm{RTNS}_{\mathrm{i}, \mathrm{t}} \quad=$ abnormal return standarisasi sekuritas ke-i pada hari ke-t di periode peristiwa

$\mathrm{RTN}_{\mathrm{i}, \mathrm{t}} \quad=$ abnormal return sekuritas ke-i pada hari ke-t di periode peristiwa.

$\mathrm{KSE}_{\mathrm{i}} \quad=$ kesalahan standar estimasi untuk sekuritas ke-i

3).Menghitung standarisasi abnormal return untuk portofolio k-buah sekuritas pada hari ket (Jogiyanto, $2017: 691$ ).

$\mathrm{RTNS}_{\mathrm{t}}=\frac{\sum_{i=1}^{k} R T N S_{i t}}{\sqrt{k}}$

$\mathrm{RTNS}_{\mathrm{t}} \quad=$ abnormal return standarisasi portofolio untuk hari ke-t di periode peristiwa

RTNS $_{i, t} \quad=$ abnormal return standarisasi sekuritas ke-i pada hari ke-t di periode peristiwa $\mathrm{k}=$ jumlah sekuritas

4). Kemudian nilai t-hitung portofolio tersebut, dibandingkan atau dikomparasi dengan nilai t-tabel. Uji signifikansi yang digunakan yaitu menggunakan nilai probabilitas $5 \%$. Jika t-hitung $>$ t-tabel, maka hipotesis kedua memiliki abnormal return yang signifikan.

\section{HASIL DAN PEMBAHASAN}

Berdasarkan informasi pada website idx pada daftar saham berdasarkan sektor hingga bulan april 2020, terdapat 18 perusahaan sektor kesehatan yang terdiri dari dua subsektor yaitu perusahaan subsektor jasa \& peralatan kesehatan dan perusahaan subsektor farmasi \& riset kesehatan. Dari 18 perusahaan sektor kesehatan terdapat 14 perusahaan sektor kesehatan yang masuk dalam kriteria sampel, dimana empat perusahaan yang tidak masuk sampel diantaranya dua perusahaan melakukan aksi korporasi buy back saham, satu perusahaan melakukan aksi korporasi pembagian dividen dan buy back saham, dan satu perusahaan sedang mengalami delisting sehingga tidak terdapat historical price dalam perdagangan. Sehingga sampel sektor kesehatan dalam penelitian ini sejumlah 14 perusahaan.

Dari hasil uji normalitas data saham sektor kesehatan nilai sig. sebelum dan sesudah penetapan peristiwa Covid-19 sebagai pandemi oleh WHO bernilai lebih besar dari 0.05 (sig. > 0.05). Dengan demikian, asumsi normalitas sudah dipenuhi sehingga data yang digunakaan sudah ber-distribusi normal. 
Tabel 1. Hasil Uji Normalitas Data Saham Sektor Helathcare

\begin{tabular}{|l|r|r|r|r|r|r|}
\hline & Tests of Normality \\
\cline { 2 - 7 } & Statistic & df & Sig. & Statistic & df & Sig. \\
\hline K_Sebelum & .135 & 20 & $.200^{*}$ & .946 & 20 & .315 \\
K_Sesudah & .189 & 20 & .058 & .903 & 20 & .047 \\
\hline
\end{tabular}
*. This is a lower bound of the true significance.
a. Lilliefors Significance Correction
Sumber: olah data, SPSS 13.0 for Windows. (2021)

Tabel 2. Hasil Uji Hipotesis Kesatu Sektor Helathcare

Dari hasil pada tabel 2. dapat diinterpretasikan bahwa nilai sig. sebesar 0.151 yang berati lebih besar dari tingkat signifikansi 0.05 (sig. > 0.05), selain itu nilai t-hitung didapatkan sebesar -1.495 dibandingkan dengan nilai t-tabel sebesar 2.093. Dengan demikian, dapat dimaknai secara statistik bahwa tidak ada perbedaan abnormal return saham sektor healthcare yang signifikan antara periode sebelum dan periode sesudah peristiwa pengumuman penetapan Covid-19 sebagai pandemi oleh WHO, sehingga hipotesis kesatu untuk sektor kesehatan ditolak.

Namun, secara matematis terlihat adanya perubahan dari nilai rata-rata atau mean dari abnormal return saham sektor healthcare pada periode sebelum peristiwa menunjukkan nilai negatif $(-0.0019)$ menjadi nilai yang positif (0.0087) pada sesudah peristiwa. Hal ini dapat diartikan bahwa sebenarnya saham sektor kesehatan memberikan sinyal yang positif terhadap peristiwa pengumuman penetapan covid-19 sebagai pandemi oleh WHO. Dapat didukung oleh gambar 5. bahwa pergerakan rata-rata abnormal return saham sektor healthcare pada periode jendela menunjukkan pergerakan yang meningkat.

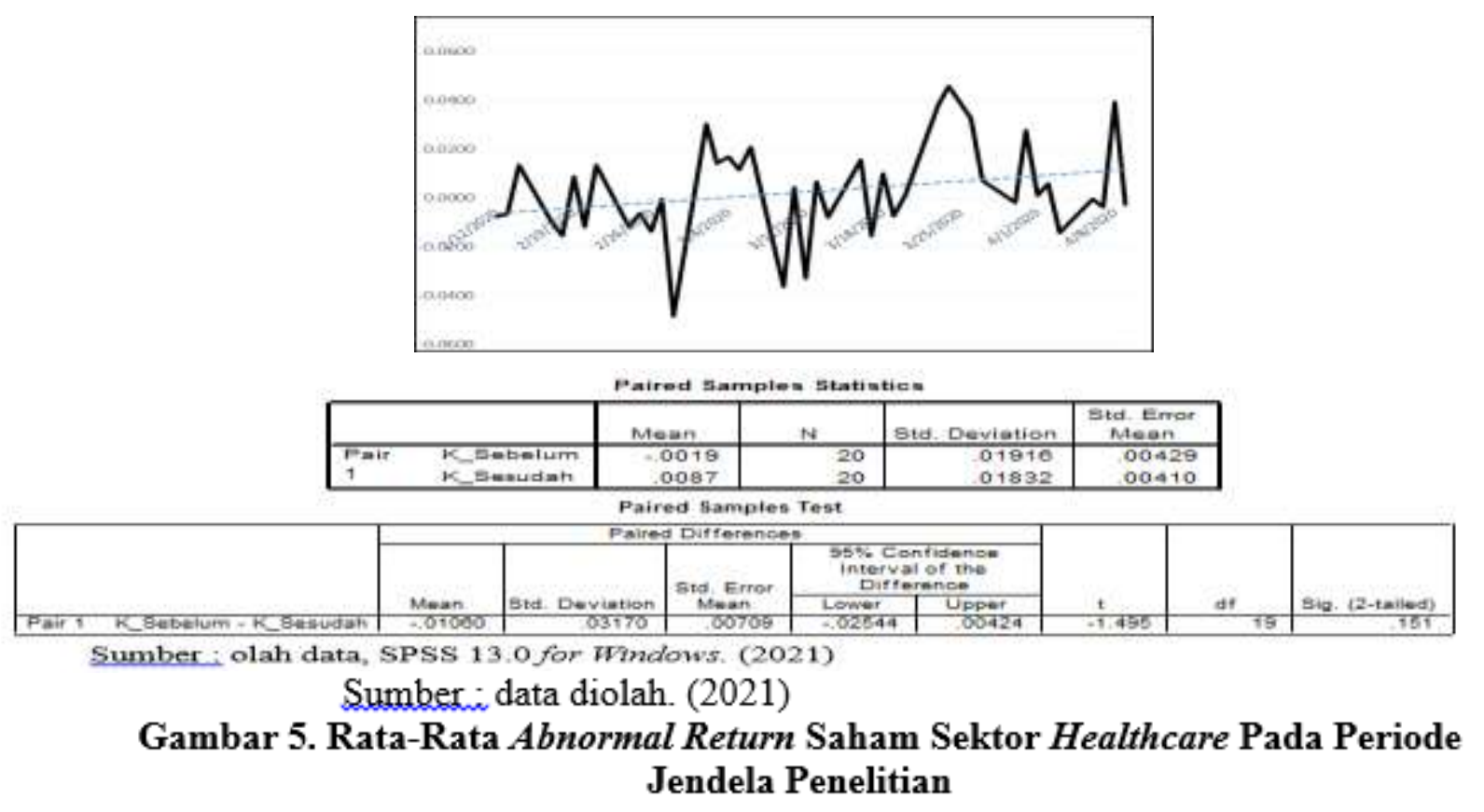


Dengan demikian, meskipun tidak ada perbedaan yang signifikan namun rata-rata abnormal return saham sektor healthcare menunjukkan adanya peningkatan atau reaksi positif.

\section{Hipotesis Kedua}

Berdasarkan tabel 3. terlihat bahwa pada periode sebelum peristiwa terdapat 1 (satu) hari yang memiliki abnormal return yang signifikan yaitu $\mathrm{t}-4$, dimana terjadi abnormal return yang positif yaitu 0.0114 . Sedangakan, pada periode setelah peristiwa terdapat 7 (tujuh) hari yang memiliki abnormal return signifikan yaitu $t+9, t+10, t+11, t+13$, $t+15, t+17$, dan $t+19$. Nilai rata-rata abnormal return yang signifikan menunjukkan angka positif dan hanya sekali menunjukkan angka negatif pada $t+17$. Dapat dikatakan masih terjadi pergerakan fluktuatif setelah menunjukkan angka postif kemudian pada $t+17$ menujukkan angka yang negatif tetapi hal tersebut dikoreksi kembali pada $t+19$ yang kembali menunjukkan positif. Sementara itu, pada t0 justru tidak terdapat abnormal return yang signifikan.

Tabel 3. Hasil t-Hitung Standarisasi Selktor Kesehatan Per Tanggal Pada Periode Jendela

\begin{tabular}{|c|c|c|c|}
\hline Tanggal & Harike-t & Rata-rata abnormal retiurn & t-hitung \\
\hline $2 / 12 / 2020$ & -20 & -0.0077 & -0.25248 \\
\hline $2 / 32020$ & -19 & -0.0066 & 0.37755 \\
\hline $2 / 142020$ & -18 & 0.0132 & 0.79776 \\
\hline $2 / 17 / 2020$ & -17 & -0.0102 & -1.41535 \\
\hline $2 / 18 / 2020$ & -16 & -0.0157 & -1.12726 \\
\hline $2 / 92020$ & -15 & 0.0087 & 1.06538 \\
\hline $2 / 20 / 2020$ & -14 & -0.0118 & 0.30300 \\
\hline $2 / 21 / 2020$ & -13 & 0.0133 & 0.13688 \\
\hline $2 / 242020$ & -12 & -0.0120 & 0.18410 \\
\hline $2 / 25 / 2020$ & -11 & -0.0064 & -1.45310 \\
\hline $2 / 262020$ & -10 & -0.0138 & -1.97713 \\
\hline $2 / 27 / 2020$ & -9 & -0.0006 & -0.78778 \\
\hline $2 / 28 / 2020$ & -8 & -0.0486 & -5.85310 \\
\hline $3,2,2020$ & -7 & 0.0301 & 1.40855 \\
\hline $3 / 3 / 2020$ & -6 & 0.0140 & 1.05108 \\
\hline $3,4 / 2020$ & -5 & 0.0167 & 1.57914 \\
\hline $3 / 5 / 2020$ & -4 & 0.0114 & 2.17048 \\
\hline $3,6 / 2020$ & -3 & 0.0208 & 0.11462 \\
\hline $3,9 / 2020$ & -2 & -0.0365 & -5.32712 \\
\hline $3 / 10 / 2020$ & -1 & 0.0040 & 1.79306 \\
\hline $311 / 2020$ & 0 & -0.0331 & -3.62765 \\
\hline $3 / 12 / 2020$ & 1 & 0.0065 & -1.25522 \\
\hline $3 / 13 / 2020$ & 2 & -0.0080 & -1.34594 \\
\hline $3 / 16 / 2020$ & 3 & 0.0154 & -0.72776 \\
\hline $3 / 17 / 2020$ & 4 & -0.0156 & -5.12504 \\
\hline $3 / 18 / 2020$ & 5 & 0.0098 & -1.73302 \\
\hline 3192020 & 6 & -0.0074 & -5.55471 \\
\hline $3 / 20,2020$ & 7 & 0.0010 & -2.49674 \\
\hline $3 / 23 / 2020$ & 8 & 0.0379 & -2.07294 \\
\hline $3 / 242020$ & 9 & 0.0455 & 2.09745 \\
\hline $3 / 26 / 2020$ & 10 & 0.0324 & 9.25229 \\
\hline $3 / 27 / 2020$ & 11 & 0.0069 & 3.84070 \\
\hline $3 / 30 / 2020$ & 12 & -0.0019 & -0.46081 \\
\hline $3 / 31 / 2020$ & 13 & 0.0275 & 10.98722 \\
\hline $4,1 / 2020$ & 14 & 0.0010 & -0.53913 \\
\hline 4222020 & 15 & 0.0058 & 3.52490 \\
\hline $4 / 3 / 2020$ & 16 & -0.0143 & -0.82859 \\
\hline $46 / 2020$ & 17 & -0.0007 & 2.90622 \\
\hline 4772020 & 18 & -0.0039 & -0.93163 \\
\hline $4 / 8 / 2020$ & 19 & 0.0391 & 2.49455 \\
\hline $4 / 9 / 2020$ & 20 & -0.0027 & -0.08979 \\
\hline
\end{tabular}

*) Signifikansi dengan tingkat probabilitas 0.05 (t hitung $>2.02108$ ) Sumber; data diolah, Ms. Excel 2013. (2021) 
Berdasarkan hasil output data tersebut, dapat diberi simpulan bahwa periode sebelum dan periode sesudah peristiwa dapat diterima dimana artinya terdapat abnormal return yang signifikan, baik pada periode sebelum maupun sesudah peristiwa. Sementara pada saat terjadinya peristiwa berarti tidak terdapat abnormal return saham yang signifikan pada saat pengumuman penetapan covid-19 sebagai pandemi oleh WHO.

Dengan demikian, adanya abnormal return saham yang signifikan di sekitar periode jendela tersebut menunjukkan bahwa peristiwa penetapan Covid-19 sebagai pandemi oleh WHO memiliki kandungan informasi yang memberi sinyal positif atau direspon positif oleh pasar khususnya untuk sektor healthcare.

\section{E. KESIMPULAN}

Terdapat perbedaan yang tidak signifikan pada sektor healthcare dapat dijelaskan bahwa pelaku pasar masih bersikap lebih waspada dalam mengitung dampak kedepanya secara jangka panjang, sehingga tidak terburu-buru dalam melakukan tindakan, pasar tidak dapat secara cepat dan tepat dalam mengukur dampak peristiwa terhadap saham sektor healthcare sehingga investor cenderung wait and see. Investor kurang rasa percaya dan belum banyak pengalaman dalam memprediksi dampak pandemi terhadap berbagai sektor. Meskipun begitu, reaksi harga saham terlihat dari pergerakan rata-rata sektor kesehatan mengalami kenaikan.

Terdapat indikasi bahwa investor lebih merespon informasi pada hari setelah pengumuman penetapan Covid-19 sebagai pandemi oleh WHO karena jumlah abnormal return lebih banyak terjadi daripada spot waktu abnormal return sebelum peristiwa. Dapat disimpulkan bahwa kandungan informasi peristiwa tersebut terlambat direspon oleh pelaku pasar karena dirasa dampak peristiwa terbesut berkepanjangan bagi return yang dihasiklan.

\section{Saran}

Sebagai pelaku pasar juga harus lebih mencermati dampak dari suatu peristiwa, adanya peristiwa pandemi Covid-19 ini dapat dijadikan pengalaman bagi pelaku pasar kedepanya untuk lebih tepat dalam menganalisis dampak suatu peristiwa terhadap beberapa sektor.

\section{Implikasi Hasil}

Penelitian ini memberikan suatu tambahan pada literatur studi peristiwa pasar modal Indonesia bahwa pasar tidak akan selalu memberi reaksi secara tepat dan cepat terhadap pengaruh suatu informasi. Pasar modal Indonesia belum memiliki cukup banyak pengalaman dalam menghitung dampak dari suatu peristiwa terhadap suatu sektor industri, khususnya peristiwa pandemi Covid-19 yang merupakan peristiwa yang tidak sering terjadi dan baru pertama kali pada abad ini.

Berdasarkan hasil dari penelitian sebelumnya (Hindayani, 2020) disimpulkan tidak terdapat perbedaan cumulative abnormal return subsektor farmasi, telekomunikasi, dan makanan minuman pada periode sebelum dan sesudah pengumuman kasus terkonfirmasi Covid-19 pertama kali di Indonesia.

Dengan demikian, penelitian tersebut mendukung penelitian ini bahwa reaksi yang dihasilkan pada sektor kesehatan juga terdiri dari subsektor farmasi menunjukkan reaksi pasar yang positif atau sinyal yang baik.

\section{Keterbatasan Pada Penelitian}

Hasil penelitian sangat diharapkan bisa memberi gambaran tentang peristiwa pandemi Covid-19 terhadap reaksi saham suatu sektor industri, sehingga dapat dijadikan referensi untuk penelitian-penelitian studi peristiwa terhadap suatu sektor industri pada penelitian-penelitian berikutnya. Akan tetapi, penelitian yang telah dilakukan ini juga masih 
mempunyai keterbatasan yaitu sampel dari penelitian ini hanya khusus sektor kesehatan di Bursa Efek Indonesia.

Dengan demikian, untuk penelitian selanjutnya dapat menambah jumlah sampel suatu sektor agar lebih memberikan hasil yang lebih akurat dalam megetahui perbedaan reaksi-reaksi pasar. Selain itu, juga bisa menggunakan model expected return lainya untuk mengetahui perbedaan output yang dihasilkan.

\section{DAFTAR PUSTAKA}

Hindayani, N. (2020). ANALISIS REAKSI PASAR SAHAM ATAS PERISTIWA COVID-19. $4(3), 1645-1661 . '$

Husain, T., \& Sunardi, N. (2020). Firm's Value Prediction Based on Profitability Ratios and Dividend Policy. Finance \& Economics Review, 2(2), 13-26.

Jogiyanto (2017) 'TEORI PORTOFOLIO DAN ANALISIS INVESTASI EDISIS KESEBELAS', Yogyakarta, BPFE-Yogyakarta

Jogiyanto (2018) 'STUDI PERISTIWA Menguji Reaksi Pasar Modal Akibat Suatu Peristiwa', Yogyakarta, BPFE-Yogyakarta

Muliati, N. K. (2020). Pengaruh Perekonomian Indonesia di Berbagai Sektor Akibat Corona Virus Disease 2019 (Covid-19). Widya Akuntansi Dan Keuangan, 2(2), 78-86. https://doi.org/10.32795/widyaakuntansi.v2i2.874

Priyastama, R. (2020) 'THE BOOKS OF SPSS Pengolahan \& Analisis Data' START UP, Yogyakarta.

Sunardi, N. (2019). Profitabilitas, Likuiditas, Dan Multiplier Equity Pengaruhnya Terhadap Harga Serta Return Saham Pada Industri Manufaktur Tahun 2012-2017. Inovasi, 6(1), 58-73.

Sunardi, N., \& Ula, L. N. R. (2017). Pengaruh BI Rate, Inflasi Dan Kurs Terhadap Indeks Harga Saham Gabungan (IHSG). Jurnal Sekuritas: Saham, Ekonomi, Keuangan dan Investasi, 1(2), 27-41.

Suganda, T. R. (2018) 'Event Study Teori dan Pembahasan Reaksi Pasar Modal Indonesia' Malang : CV. Seribu Bintang

Tandelilin (2001) 'ANALISIS INVESTASI DAN MANAJEMEN PORTOFOLIO', Yogyakarta, BPFE-Yogyakarta

Wahidmurni (2017) 'PEMAPARAN METODE PENELITIAN KUANTITATIF' , UIN Maulana Malik Ibrahim Malang, Malang

WHO. (2020). Coronavirus Disease 2019 (COVID-19) World Health Situation Report - 1. WHO Indonesia Situation Report, 2019(March), 8.

www.idx.co.id/perusahaan-tercatat/aksi-korporasi/ diakses pada tanggal 02 Februari 2021 pukul 23:12 WIB

www.idx.co.id/data-pasar/data-saham/daftar-saham/ diakses pada tanggal 02 Februari 2021 pukul 21:59 WIB 